\title{
Modern Russian Writers on the German Book Market
}

\author{
Adriana Pogoda-Kolodziejak* \\ Siedlce University of Natural Sciences \\ and Humanities \\ 2 Konarskiego Str., Siedlce, 08-110, Poland
}

Received 10.01.2017, received in revised form 25.02.2018, accepted 12.03.2018

The purpose of this article is to review trends concerning the presence of contemporary Russian writers on the book market in Germany. The interest of the German readers in the Russian literature dates back to the 19th century. However, over the years the list of books has significantly changed. In addition to the attention to the classical literature, there appeared interest in the works of immigrants, dissidents and writers banned in the Soviet Union. At the present time Russian classics is still being published. Moreover, German readers are very keen on reading both writers who are successful in Russia and the authors constantly living abroad, including German-speaking countries.

Keywords: reception, book market, Russian writers, contemporary literature, Germany.

DOI: 10.17516/1997-1370-0236.

Research area: philology.

\section{Historical review}

The appearance of the Russian literature in Germany and the establishment of literary contacts between Russia and Germany can be dated no earlier than the $19^{\text {th }}$ century. It was at this time that both states became interested in each other, which has promoted mutual penetration of cultures. In the 1840s the German translation of F.M.Dostoevsky's novel Poor People was published right after its Russian edition. Russian culture was considered as secondary in Germany, which was partly due to the political situation (Russia did not want to allow the unification of Germany, threatened it with an invasion and interfered in its internal affairs), but nevertheless,
V.A.Zhukovsky had fruitful contacts with German writers, while Varnhagen von Ense studied Pushkin's works enthusiastically (Weintraub, 1949: 1). The first German magazine (edited by Wilhelm Wolfsohn) with the Russiaoriented theme "Russisches Revue" was founded in 1862, after Bismarck came to power.

The first Russian writer who influenced German literature was I.S. Turgenev, who lived in Germany and maintained relationships, in particular, with such writers as Theodor Strohm and Gustav Freytag. Fashion for Russian literature in Germany came together with the "naturale Schule", along with the texts of L.N. Tolstoy and F.M. Dostoevsky, who "impress the German

(c) Siberian Federal University. All rights reserved

* Corresponding author E-mail address: nkovtun@mail.ru 
reader with the freshness of the approach, the fact that they do not follow the conventions, that they try to imagine life as it is, do not refuse to depict its unpleasant and disgusting aspects" (Weintraub, 1949: 2). German readers did not pay attention to the religious or ethical side of their works, but treated them as great realistic authors. I should give emphasis to the fact that actually people reading Tolstoy or Dostoevsky were not very interested in Russia and Russian realities. Most of all they paid heed to the person as such, longing to study themselves better. Thanks to the fact that this literature touched on the same themes as the literature of other European countries, it became a permanent component of German cultural life, relatively independent of any political relations.

Over time, the attitude to Russian literature has begun to change. Before World War I, M. Gorky was very popular in Germany; thanks to the tours of the Stanislavsky Theatre in 1906 the Germans discovered for themselves a Russian theatre. The influence of Russian writers can be traced in the works of German writers, namely, The Fool in Christ: Emmanuel Quint by Gerhart Hauptmann, or The Fool by Bernhard Kellermann, which are directly related to the novel Idiot by F.M. Dostoevsky, whose popularity in Germany dates back to the times after World War I. At that period the admiration for his work became a trigger for a deep study of the works by the Russian prose writer. There and then he was worshiped as a great inspirer of religious enlightenment. The most remarkable lovers of his works include the German Catholic theologian Guarini and art critic Julius MeyerGraeffe. It should also be taken into account that before World War I in Germany Baron A. von Haxthausen carried out extensive scientific research on Russia, especially on its history. At the present time, while studying the history of Russia in the $19^{\text {th }}$ century one shall not neglect the works of such German historians as T. Schiemann or K. Stählin. There was also published a magazine Kyrios (Weintraub, 1949: 3) dedicated to religious issues.

In the 1920s interest in Soviet literature was quite broad, but with a political tinge and, above all, it was dominating in radical left circles. In the 1930s, due to unfavourable political relations, this interest decreased. During the USSR existence, the German Democratic Republic translated the books of Russian writers who followed the Soviet canon, whereas the Federal Republic of Germany translated Russian exiled writers. Soviet classics entered the market of West Germany only after the historical changes. Meanwhile, there appeared the works, which used to be published almost exclusively in samizdat. The list of authors includes Osip Mandelstam, Mikhail Bulgakov, Andrei Bitov, Venedikt Erofeev and Anna Akhmatova. Many texts were printed, however, in a censored form. After admiration for Gorbachev had diminished, Russian literature in Germany ceased to attract readers' interest. Vladimir Grigoryev, Deputy Head of the Federal Agency for Press and Mass Communications of the Russian Federation, accused the West of this state of affairs. After the collapse of the Soviet Union, there was a prevailing belief that Russia would soon begin to publish new great literature in the largest publishing houses of the world, as it usually happened in the history of civilized world after the grand changes. However, this did not happen, and therefore interest in Russia faded (Iwanowski, 2003: 2-3).

In the 1990s, Russian literature experienced a wave of freedom and the market was filled with books, publication of which had been unthinkable in the USSR conditions. These were numerous works of émigré literature and samizdat works. There was literature about topics which were considered taboo at this time, namely, sex, death, drugs, crime, homosexuality, the war in Afghanistan, Gulag camps, political 
repression. Such stories are one of the subjects among others in the works of Russian writers who were very popular in Germany then (Victor Pelevin, Vladimir Sorokin, Eduard Limonov, Viktor Erofeev, etc.).

\section{The situation today}

Now, 27 years later, we deal with Russian writers who were born in the USSR and live in German-speaking countries and write in German. The list of such authors contains the names of Vladimir Vertlib, Julia Rabinovich, Lena Gorelik, Olga Martynova, Olga Gryaznova and Wladimir Kaminer, who is a favourite of German readers for the themes of his works, which reflect Russian-Jewish-German culture. Thanks to these writers German literature enriched with such themes as the Leningrad blockade, hunger, anti-Semitism and Jewish processes in the Soviet Union, and reflection on migration.

There is also a group of writers, the so-called Russian Germans, of whom the most famous is Eleonora Hummel, followed by such authors as Nelly Däs, Wendelin Mangold, Alexander Reiser, Nelly Wacker and Ilona Walger. Many of them are called the "fourth wave" of emigrants from Russia to Germany (Kasack, 1996: 11-19; Tichomirova, 2000: 166-176). The main difference between this group and the previous "three waves" of emigrants is that the "fourth wave" began to write books in German, while the previous Russian émigrés wrote their works primarily in Russian, although Fedor Stepun, Vladimir Lindenberg and Aliya Rakhmanova published their creations also in German, the language of Goethe.

Here it is worthwhile to pause and pay attention to the contemporary RussianGerman writer Eleanora Hummel (1970), who made her debut in Germany in 2005 with her autobiographical novel Die Fische von Berlin (The Fish of Berlin). Her consequent novels received numerous literary awards. They touched upon earlier forbidden topics - the history of Russian-German families, their past life during the Third Reich. Her new novel In guten Händen, in einem schönen Land (In Good Hands, in a Beautiful Country, 2013) describes the fate of the women in the Soviet labour camp, creating a very realistic, even documentary epic. The narration about the story of Olesya Lepanto transfers the reader into the Soviet reality. This talented student of the theatre school was sent to a labour camp in 1942, where she gave birth to her daughter Victoria. Together with Nina, her friend in this misfortune, they are fighting for the child's survival. The whole story really brings the German reader closer to the mishaps of the Russians in their own country. In her review for Frankfurter Rundschau Cornelia Geisler gave an excellent assessment of the book, summing up its essence in exact words: "drama of life spoiled by state" (Cited in Geißler, 2013).

Another bilingual writer worth paying attention is Valdemar Weber, the author of lyrical works, essays and short prose texts. He received multiple awards for his works both in German and in Russian, including the first prize of the International Competition named after Anatoly Makovsky. He was also a populariser of RussianGerman writers in the USSR, translating the works of Viktor Heinz, Arno Pracht, Oswalda Pladers and other writers into Russian.

\section{Russian books on the German market}

Here there arise some questions: which books do Russians who live in Germany read? And what Russian books are currently translated into German?

In the bookstores we can find new editions of the classical works by A.S. Pushkin, F.M. Dostoevsky, L.N. Tolstoy; novels of contemporary postmodern writers Victor Pelevin, Tatyana Tolstaya and Vladimir Sorokin; books of 
so-called "mass literature" - detectives by Boris Akunin, Alexandra Marinina, novels by Polina Dashkova, Darya Dontsova, and science fiction by Sergei Lukyanenko or Dmitry Glukhovsky. The books of the above-mentioned writers have been translated into German, although some of them can also be bought in Russian at bookstores such as Gelikon or Russisches Haus in Berlin, or, interestingly, in supermarkets that offer authentic Russian food to their customers. In the West, this is a common practice, as many shops offering goods from other countries start selling their books too.

Currently we can distinguish new Russian writers who at the beginning of this century dared to enter the Western market and since then have been regular guests for one of the most prestigious readership and publishing events in Germany - Frankfurter Buchmesse (Frankfurt Book Fair) for several years. In 2012, the publisher Irina Prokhorova the discussion forum with the writers Dmitry Glukhovsky and Mikhail Shishkin and the translator Dorothea Trottenberg. Their talk was devoted to the functioning of Russian literature outside of Russia. The moderator Thomas Wiedling from Nibbe \& Wiedling Literary Agency posed some acute questions at the very beginning. "Who do we consider to be a real Russian writer? Does the image of Leo Tolstoy with his gray-haired beard covering half of his face impose any expectations on future Russian writers? Should Russian literature be similar to the novel Doctor Zhivago? What explains Wladimir Kaminer's success in Germany? How does the road to success look like?" (Cited in Weimarn, 2012).

Mikhail Shishkin said that he is happy when the authors quickly achieve success, but unfortunately, it does not happen so easily. Publishers believed that his own novels are too complicated for the reader. When the publishing house in Germany, thanks to the efforts of his literary agent, decided to publish his novel finally, the expected success came. Being a Russian writer, he experienced the burden of a stereotype that a Russian writer in a foreign country is sipping vodka and dying from missing the homeland. In Shishkin's opinion, the time has come for Russian writers to return to the stage of modern world literature. He is deeply convinced that the $21^{\text {st }}$ century will allow any writer to live abroad and at the same time remain Russian (Cited in Weimarn, 2012).

Dmitry Glukhovsky, known primarily as the author of the Metro cycle, is a completely different story concerning the appearance of his books on the German market, as his texts are the part of a entirely different segment of the publishing market. Glukhovsky believes that Shishkin is closer to the classical image of an intelligent Russian writer than he is. He is perceived as the author of entertaining literature. And all this has nothing to do with his origin or the literary genre in which he works, since science fiction has long been associated with the literature of the future and has become one of the favourite genres of readers.

Irina Prokhorova claims that the publishers spent many years searching for books that would fit in the West canon of Russian literature. In recent years, one can notice a great interest in Russian literature and attention to translators, who contribute to the success of this or that work. The German translator of Russian literature Dorothea Trottenberg emphasizes that the translator needs to work with a writer to translate the book well and achieve the expected success.

The image of a new Russian society, reflections on the era in which we live and postapocalyptic scenarios are the main themes that have emerged in Russian literature in the first two decades of the $21^{\text {st }}$ century. They meet the interests of German readers in full. Along with the mass literature that lures the reader with an 
entertaining "light reading" there is intellectual prose too. Zakhar Prilepin asserts that after 2000 Russian literature has been imbued with apocalyptic premonitions with a characteristic return to social and critical realism, in which the sense of the end of the humankind is approached as a criterion of morality and understanding of human. The best example of such literature is one of the most famous projects in the world Universe of Metro 2033, created on the basis of the novel Metro 2033 by Dmitry Glukhovsky. This writer, who "has conquered" the Internet with his imaginative works, is currently the most popular Russian writer among a young generation of German fans of the science fiction genre. In addition to the typically commercial portals, such as Amazon or eBay, Gluhovsky's works established a foothold on German book sites on which Metro received the highest rating. Let me cite one of the reader's recommendations: "I really liked this book, I think that it keeps you in suspense, and in some places it becomes frightening [...] It is hard to believe that these new living beings could develop only in two decades. In addition, I have nothing to reproach Metro 2033", or: "This novel really surprised me and proved again that Russians can write good stories"1.

Suddenly, there appeared a new concept "orthodox bestseller", under which critics understand the phenomenal success of stories about the life of Russian priests written by Archimandrite Tikhon. The book Nicht heilige Heilige und andere Erzählungen (Everyday Saints and Other Stories) has sold over a million copies and spawned a new specialised market with abundant works imitating the predecessor. The next fashionable literary trend, popular with the German readers, is the interest in popular science books, biographies, essays on travel and realistic stories with elements of fiction. At present in Germany the most famous writers of this genre are Dmitry Bykov and Olga Slavnikova (Tweritina, 2013). Here we should mention Lyudmila Ulitskaya, who gained great popularity thanks to the way she shows social and ethical problems. Many readers consider her a defender of morality.

In 2014/2015, there appeared an official website of the project called Russjahr.de, the year of the Russian language and Russian literature in Germany. This was the main platform containing information about activities that should cause the Germans' interest in the Russian culture and literature. The project originated in cooperation with the Russia Beyond The Headlines website. Along with the information about the events the website contains materials for translators and teachers of the Russian language: articles, multimedia, dictionaries, interviews with philologists, translators and writers. For the first time this site was presented on June 6, 2014 in the Berlin State Library during the opening of the Year of the Russian Language and Russian Literature in Germany.

At the same time, the Year of the German Language and German Literature was held in Russia. Over 200 different events took place: seminars, conferences, translation master classes, lectures and talks in both countries. Obviously, this kind of initiative had a huge impact on the growth of interest in Russian literature among the Germans. On the site one can find reviews of newly published books by Russian writers, such as the book by Mikhail Prishvin Der irdische Kelch (Worldly Cup), in which the author criticizes the destruction of the Russian peasantry by the revolution, or Frühling auf dem Mond (Spring on the Moon) by Ukrainian-Russian-German writer Julia Kisina, who recalls her childhood in Kiev and shows the 1970s in the USSR with people who were able to sell the soul to the devil for the sake of building communism. In contrast to this, the debut of Alisa Ganieva Die russische Mauer 
(Russian Wall) shows an area on the borderlands of Europe - the Caucasus.

\section{Conclusion}

Clearly, within the framework of one article it is impossible even to mention all Russian writers who have found their place in the German market, since this list is constantly changing with publishing of new authors who are not only debuting writers, but also already well-known and famous ones. In the beginning, in the $19^{\text {th }}$ century, the presence of Russian literature in the German market depended on the political situation and the relationship between the two countries. Since the beginning of the $21^{\text {st }}$ century there has been an increasing interest in Russian books. It seems hardly connected with contacts between Russia and Germany. At the present time, given the tremendous opportunities for free distribution of literature, as well as the advantage of good Public Relations, it would be difficult to stop the penetration of Russian books into the Western market, especially since the works of many Russian writers in Germany are waited for very much as they have been firmly established in the European literature canon.

1 Available at: http://www.buecher.de/shop/science-fiction--fantasy/metpo-2033metro-2033-russische-ausgabe/glukhovskydmitry/products_products/detail/prod_id/39679959/

\section{References}

Geißler, C. (2013). Rezensionsnotiz zu Frankfurter Rundschau [Review note to Frankfurt Rundschau], available at: https://www.perlentaucher.de/buch/eleonora-hummel/in-guten-haenden-ineinem-schoenen-land.html

Iwanowski, A. (2003). Freie Menschen lesen wenig. Das postkommunistische Russland und die Literatur [Free people read little. The post-communist Russia and the literature], In Wiener Zeitung, 10.10.2003, available at: http://www.uni-siegen.de/phil/archiv/europaliterarisch/dokumentation/ vortrag/eurolit_poerzgen.pdf.

Kasack, W. (1996). Die russische Schriftsteller-Emigration im 20. Jahrhundert. Beiträge zur Geschichte, den Autoren und ihren Werken [The emigration of Russian writers in the $20^{\text {th }}$ century. Contributions to the history, the authors and their works], 11-19. Munich, 1996.

Tichomirova, E. (2000). Literatur der russischen Emigrant/innen [Literature of Russian emigrants], In Chiellino C. (ed.) Interkulturelle Literatur in Deutschland [Intercultural literature in Germany]. Stuttgart, Ein Handbuch.

Tweritina, A. (2013). Die russische Literatur im 21. Jahrhundert [Russian literature in the $21^{\text {st }}$ century], In Russland HEUTE, available at: https:/de.rbth.com/lifestyle/2013/08/13/die_russische_ literatur_im_21_jahrhundert_25425.

Weintraub, W. (1949). Rosja w kulturze zachodu [Russia in the culture of West], In Kurs Spraw Wschodnich, Seria IV, zeszyt 1. London, Publishing House of Instytut Bliskiego i Środkowego Wschodu "Reduta".

Weymarn, B.P. (2012). Literaturmarkt: Russische Literatur im Aufwind [Literature market: Russian literature on the rise], In Russland HEUTE, available at: https://de.rbth.com/articles/2012/10/29/ literaturmarkt_russische_literatur_im_aufwind_17137. 


\title{
Современные русские писатели
}

\section{на книжном рынке Германии}

\author{
А. Погода-Колодзеяк \\ Естественно-гуманитарный университет \\ в г. Седльие \\ Польша, 08-110, Седльие, ул. Конарского, 2
}

Целью настоящей статьи является обзор тендениий, касающихся присутствия современньх русских писателей на книжном рынке Германии. Заинтересованность немеикого читателя русской литературой восходит к ХІХ столетию. Однако на протяжении многих лет перечень книг значительно менялся. Наряду с всегда читаемой классикой появлялся интерес к творчеству эмигрантов, диссидентов, к запрещенным в СССР писателям. В настоящее время попрежнему издается русская классика. Кроме того, читательская аудитория Германии проявляет большой интерес клитераторам, пользуюшимся успехом в России, а такжек авторам, постоянно живущим за границей, в том числе в немецкоязычных странах.

Ключевые слова: рецепиия, книжный рынок, русские писатели, современная литература, Германия.

Научная специиальность: 10.00 .00 - филологические науки. 